\title{
Abrasándonos en el Abrazo de la Serpiente. Esbozo ensayístico acerca de la película colombiana "El Abrazo de la Serpiente", dirigida por Ciro Guerra
}

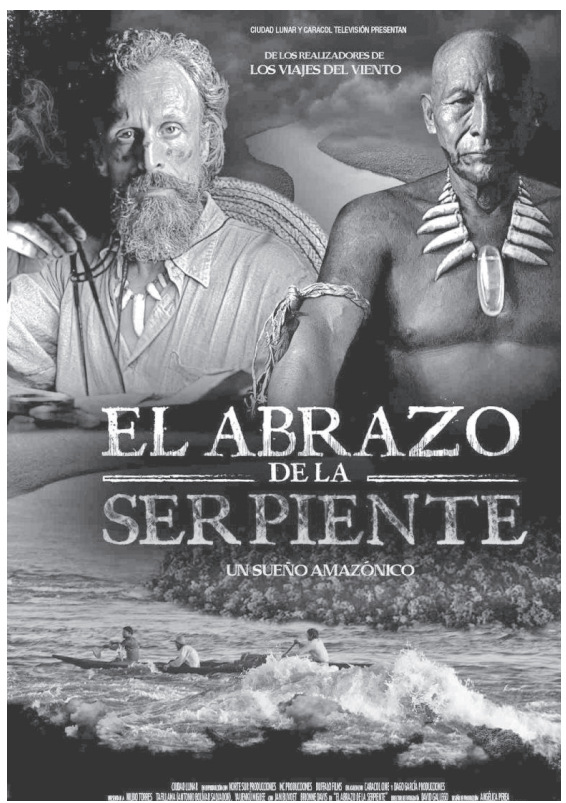

\section{Ricardo Antonio Marin Baena}

Escuela Militar de Cadetes, Bogotá, Colombia. Helenista y latinista egresado del Instituto Caro y Cuervo, Bogotá, Colombia. Corrector de Estilo en ciencias políticas y sociales y filosofía. Comentarios a: krishnaji7co@yahoo.com

Un doble viaje en el eterno retorno de un mismo anhelo, sólo alcanzable mediante el sueńo iniciático. Penetrando la Amazonia en canoa los serpenteantes ríos Putumayo, Amazonas y Caquetá, para enconar la eterna violación de que el hombre blanco, con sus codicias e intelecto, sigue destruyendo la principal sacralidad: madre naturaleza en sus entrañas. Para este viaje tras una mítica planta panacea de todas los dolores y del gran enigma del hombre en esta Tierra, dos indígenas guías para dos hombres separados por cuarenta años en sus aventuras científicas -un etnólogo alemán y un biólogo norteamericano-; encarnando ambos indígenas el drama a que la civilización occidental sometió a aquellas culturas amerindias de los pueblos ancestrales: desplazados, aculturizados, colonizados, y, en últimas, extinguidos.

Eterno retorno de lo mismo cuyo cósmico enigma tendría que descifrar la continuidad que el segundo aventurero hace respecto del primer viajante al corazón bucólico. Hechizo de lo cual consagra el dual viaje en que a su vez se ve transportado el espectador del filme. Pues la lente cinética sumerge al observador en la salvaje belleza amazónica desde el principio: La selva tropical 
nos enreda con sus lianas aferradas en la espesura arbórea que bordea dilatados manglares y nos escupe a la pesadilla de las caucheras.

La trama del filme gira así argumentalmente en torno de dos científicos enfrentados a múltiples enredaderas tanto lingüísticas -lenguas tikuna, kubeo, huitoto y ocaina, amén de catalañol y rezagos de español, inglés y alemán-, como culturales pluriétnicas en su complejidad simbólica. La transición narrativa de la trama al nudo conflictivo del filme nos va abrasando en el abrazo de la tragedia histórica. En efecto, la férula occidental no queda indemne en su maldición de haber ejecutado el magnicidio en las caucheras, el despotismo con que las órdenes católicas y religiosas lavaron a la fuerza el cerebro de la niñez y la juventud indígenas, desterrando de paso con sus dogmas teológicos las oriundas mitologías de estas comunidades ancestrales.

$\mathrm{Y}$ justamente es en este contexto en que se va perfilando Karamakate, el único indígena rebelde a la explotación y alienación de la civilización occidental, el cual hace las veces de guía y chamán desde su temprana juventud, en primer lugar con el etnólogo alemán, y, luego, al pasar cuarenta años, ya en su plena madurez vuelve y sirve de guía, en su viaje iniciático, al biólogo gringo, en la iniciación del abrazo de la serpiente. De modo que los dos hombres de ciencia, alemán y estadounidense, fieles especímenes de la soberbia intelectual occidental tanto como de las ansias de descubrimientos, creen poseer la capacidad de auscultarlo todo desde el principio de sus respectivos viajes a través de la serpiente de ríos y selva que han de trasegar -ambos eran incapaces de sońar hasta el secreto abscóndito del hontanar de la sapiencia mítico indígena.

Por eso tanto el uno como el otro bordearán zozobrantes el abismo tanto de sí mismos como de su exótico entorno, dado que las a veces delirantes imágenes cinéticas irán también enrolando al espectador en la convicción de que no hay técnica ni método, ni raciocinio capaz de confrontar y salir airosos, ante la especie de pruebas y dificultades que el chamán Karamakate irá conduciendo y viendo desarrollarse a lo largo del acuoso sendero. Pues si surten efecto las enseńanzas que se siguen de sortear aquellas dificultades del trasiego aventurero por mor del sueńo, entre otros, entonces llegarán al hallazgo del Caapi: sagrada sustancia Yakruna inmersa en la misma tradición del Yagé y la Ayahuasca, como variantes de un mismo propósito cual es el viaje a las honduras del inconsciente. Dado que solo por medio del consumo de aquella sacra sustancia en forma de bebida, podrán auscultar en las reconditeces del sueño iniciático, revelándoseles el secreto, a saber, la cura tanto de sus almas como de sus materiales existencias.

Pero con el primer científico, el etnólogo alemán -llamado en la película Theodor Von Martius-, se encarna el "mal de Occidente civilizado" incapaz de sońar con los misterios ancestrales, inclusive después de haber tomado la Yakruna. En efecto, ya el piélago de la trama del filme nos enrostrará las arduas dificultades con que tendrá que enfrentarse el chamán Karamakate, ante los caprichos y las terquedades del etnólogo alemán: de tal manera, aquél le reprochará que nunca ha entendido por qué el "hombre blanco" tiene que andar siempre cargado con tantos equipajes, tal y como es el caso del etnólogo alemán; quien para colmo de problemas además de padecer una grave enfermedad que solo la Yakruna podrá curarle, arrastra consigo el apetito insaciable de asegurarse cosas y pertenencias -lo cual también sutilmente le reprocha Karamakate-, para tener así que mostrar y maravillar a sus coetáneos europeos y familiares, el día de su regreso y llegada a su país. 
Pues bien, al término del viaje de Karamakate y el etnólogo alemán, aquél se indignará en gran manera contra los miembros de su comunidad indigena, pues se han dejado alienar y empoderar por las órdenes religiosas invasoras, mientras el etnólogo se irá perfilando en su decadencia y fracaso respecto del objetivo central con la Yakruna y sus portentos; y ello pese a que logrará regresar a su Alemania junto con sus pertenencias y, algo definitivo y clave para la memoria histórica, se llevará consigo el Diario de campo que daría origen a toda una narrativa tanto científica como aventurera y, finalmente ahora, cinematográfica -en efecto, tanto el director de la película Ciro Guerra, como Jacques Toulemonde, basaron el guion para esta película en los diarios de Theodor Koch-Grünberg y Richard Evans Schultes, o sea los dos científicos en la vida real, el alemán y el estadounidense, a que nos venimos refiriendo en el presente esbozo ensayístico, en tanto que protagonistas del filme.

De modo entonces que fue cuarenta ańos después de las aventuras e insaciables búsquedas del etnólogo alemán, que el biólogo gringo -llamado en la película Richard Evans- emprende por su parte cual la continuidad de la misma meta científico aventurera. Llegado así al Amazonas, y en la parte terminal del nudo argumental del filme para desembocar en su desenlace, se encuentra con Karamakate, hecho ya ahora un envejecido sabio que sin embargo ha caído en el escepticismo y la amargura, y no tan solo pero sí principalmente porque confiesa haber perdido la memoria del sendero a la Yakruna - no sabiendo ya ni siquiera cómo se prepara el Mambe. La semántica simbólica de estas carencias e impotencias confesas por el viejo chamán, bien podría interpretarse como encarnando al maestro caído que yace tan dormido en su inconsciencia, y tan perdido respecto de su óptimo destino, que por eso le urge reemprender el arduo camino de búsqueda a la iniciación del reencuentro con el exigente mito y sus secretos liberadores.

Por cierto que las referencias al respecto de la doctrina secreta y esotérica están matizadas a lo interno de una cierta mitología indígena -la del chullachaqui: el cuerpo vacío o el doble vacío-, a lo cual hace mención específicamente Karamakate en un instante de clímax del filme, confesando que su desmemoria y cual pérdida de identidad se concreta en su Chullachaqui que anda vagando por el espacio, "ya sin noción de las cosas y hasta sin nombre", tal cual interpretaría la doctrina secreta y esotérica mediante el famoso "cuerpo astral lunar", peculiar al misionero cósmico que ha caído y queda desmemoriado y sin horizonte con su consciencia e inconsciencia totalmente dormidas.

El entronque de ambas necesidades existenciales latentes, la del viejo Karamakate decepcionado y en estado de pérdida de su óptimo destino, así como la del biólogo gringo Richard Evans, unificarán los horizontes de los dos hombres que, paralelamente, continuarán en pugna simbólica de confrontación de dos civilizaciones que cada vez serán más irreconciliables -pese a que el director del filme, Ciro Guerra, parece arrojar el ancla de la reconciliación intercultural. Y cual ocurriera con el etnólogo alemán hace ya cuarenta años, en este nuevo periplo por ese Amazonas tumultuoso se reencuentran con los peligros y dificultades a superar: la lucha remando en el serpenteante rio en su canoa tradicional, así como los indígenas postrados cultural, espiritual y materialmente rindiendo idolatría a un falso mesías, en medio de una comunidad en donde la simbiosis de culturas y creencias incompatibles de suyo -de Occidente religioso a indígenas raizales-, ha dado al traste con el sentido reivindicador de libertad, respeto a la otredad, autonomía y realización humanas -factor en pugna con que también nos zahiere la temática fílmica respecto de la explotación económica desalmada, por mor de la avaricia de los caucheros contra sus trabajadores humildes e indígenas. 
Y este caos de maremágnum de injusticias ocurre en un país, Colombia, y la corrosiva crítica no puede ser más evidente en torno de una república cuyos conciudadanos no salen muy bien parados en la perspectiva allí proyectada: ¿cuál es el país que seguimos deconstruyendo desde la semblanza histórica de abusos, pobreza e ignorancia?

$\mathrm{Y}$ es por eso que las imágenes del filme en esta transición del nudo al desenlace, nos apremian a huir de aquel vendaval deshumanizado; y Karamakate insta al gringo Richard Evans a emprender la marcha final a las montańas sagradas, pues es el último lugar del mundo amazónico en donde podrá encontrarse aún la Yakruna, aquella mítica planta panacea de todas los dolores y del gran enigma del hombre en esta Tierra: el chamán prepara la bebida y el biólogo se dispone ahora a tomarla para interiorizarse mediante el sueńo, que le permitirá trascender a la más íntima por abscóndita revelación interior de la selva y sus genios tutelares.

Asalta la pantalla la imagen del Jaguar como portento mágico de todas las fuerzas y energías de la serpiente en que se potencia -eco en red transhistórico y cultural de la serpiente emplumada Quetzalcōattl y sus mágicos poderes en el panteón mesoamericano-, la cual abrasa de fuego en su abrazo salvífico, y cuaja la realización en el hontanar de la naturaleza. Por eso el filme rompe en esta penúltima secuencia con la imagen humana y el espacio tiempo de un lugar cualquiera. El blanco y negro y sus matices con que el director del filme nos deleitó durante todo el relato cinético hasta aquí, se funde, y la pantalla se torna abigarrada en fulgurante color de figuras cuyo cromatismo destella símbolos en geometrías cosmogónicas: ello inspira a desciframientos y develaciones con y para y en medio de lo originario puro.

Gira entonces la imagen cinética a la última secuencia del filme. Richard Evans yace tendido al borde de la montańa sagrada, empezando ya a erguirse al acabar de despertar del mágico sueño; por cuya iluminación pudo al fin visualizar el abrazo de la serpiente mítica. Pero ya de pie, en silencio, puede constatar él, tanto como nosotros los espectadores, que el chamán y ahora consagrado Karamakate ha desaparecido. Angustiado, arrojado en la soledad del entorno, Richard Evans grita una y otra vez cual desamparado que clama al Maestro que ya no lo guiará más. La película termina. Quizás el científico gringo, último vástago de la civilización occidental en este contexto, y en aras del real acceso a la madre naturaleza, aunque logró apenas soñar con el abrazo de la serpiente al beber la Yakruna, no ha sido iniciado en rigor: Deberá comprender y luchar muchísimo más en su forjarse Jaguar auténtico de la selva para quedar de veras abrasándose en el abrazo de la serpiente.

\section{Conclusiones}

El filme se estructura en tres marcos fundamentales por contenido y forma: Uno: el antropológico humanista, consistente en la variedad étnica y lingüística de las comunidades indígenas del país, y su compleja red de problemática y derechos incumplidos. Dos: el histórico político y sociocultural económico, consistente en el proceso colonizador patente, entre otros, en la explotación del caucho y el desalmado negocio de las caucheras, así como en la aculturización y alienación de los indígenas por parte de los poderes estamentales y religiosos de Occidente. Tres: el estético y mitico cosmológico, consistente en la complejidad simbólica y conceptual y artística de la asombrosa cultura más íntima de las comunidades indígenas del país, la cual por primera vez sería reivindicada en 
su belleza y hondura con una "película de largometraje argumental" como es esta de Ciro Guerra. Los recursos en lenguaje cinematográfico, así como el propio guion, de parte del director del filme, abundan en singularidad estética - planos, tomas, secuencias, fotografía, matices del blanco y negro, movimientos de cámara-, que bien pueden clasificarse como "cinema d'auteur".

Tal compleja estructura del filme se corresponde con las controversias que ha generado en los medios tanto cinéticos como periodísticos y socio culturales -difícilmente les ha ocurrido lo mismo a otras notables películas colombianas. Dichos entusiasmos y críticas y pasiones en la polémica se corresponden con las diversas lecturas que, desde luego, suscita y potencia un filme que bien se podría conjeturar la mejor película de la historia del cine colombiano. Esta afirmación no necesariamente recae en el ditirambo, y tampoco se basa en el prejuicio esnobista por haber sido la primera película colombiana que, luego de ser nominada a los premios Oscar de Hollywood para mejor película extranjera, logró perfumarnos con el aroma del más apetecido galardón con que sueña cualquier director de cine en el mundo. Por todo ello, quizás es verosímil la convicción de que la película expone y crítica tan a fondo diversos factores que explican el subdesarrollo tanto material como espiritual de nuestros pueblos, que por eso mismo zahiere ciertos intereses imperiales y estamentarios de intrincada malla. Naturalmente, no le iban a conceder "Oscars of Academy of Motion Picture Arts and Sciences vía Hollywood". 